\title{
Essential Oil of Grape Fruit (Citrus paradisi) Peels and Its Antimicrobial Activities
}

\author{
Wahab O. Okunowo*, Olajumoke Oyedeji, Lukman O. Afolabi, Eniola Matanmi
}

Department of Biochemistry, Faculty of Basic Medical Sciences, College of Medicine, University of Lagos, Lagos, Nigeria. Email: *modelprof@yahoo.com

Received May $3^{\text {rd }}, 2013$; revised June $4^{\text {th }}, 2013$; accepted June $18^{\text {th }}, 2013$

Copyright (C) 2013 Wahab O. Okunowo et al. This is an open access article distributed under the Creative Commons Attribution License, which permits unrestricted use, distribution, and reproduction in any medium, provided the original work is properly cited.

\begin{abstract}
Plants and plant products are continuously being explored in medicine against the increasing number of antibiotic resistant organisms. The antimicrobial activity of essential oil of some plants has been demonstrated against a range of organism. This study aimed to determine the chemical constituents and the antimicrobial effects of the oil of grape peels on some clinical isolates. The oil was obtained from the peels by hydrodistillation procedure and analyzed using Gas chromatography coupled to mass spectrometer. The in-vitro antimicrobial property of the methanolic, ethanolic and tween 80 mixture of extract was determined by agar well diffusion method against selected clinical bacterial isolates (Bacillus cereus, Enterococcus faecalis, Escherichia coli, E. coli ATCC 25292, Klebsellia pneumonia, Pseudococcus sp., Salmonella typhmurium, Shigella flexneri, Staphylococcus aureus, Staphylococus aureus ATCC 29213) and fungal isolates (Aspergillus niger, Candida albican, and Penicillium chrysogenum). The GC-MS analyses of the oil indicated the amount of the essential oil components was highest with D-Limonene (75.05\%), followed by $\beta$-myrene $(7.25 \%)$, $\alpha$-pinene (2.11\%), caryophyllene (1.88\%), octanal (1.68) and $\beta$-phellandrene (1.18\%). Some of the minor components included $\delta$-cadinene $(0.89 \%)$, copaene $(0.82 \%)$, methyl phthalate $(0.54 \%)$, linalool $(0.48 \%)$ and 3 -carene $(0.21 \%)$. The oil extracts exerted different degrees of inhibitory activity against the organisms. The inhibition of the test isolates was dependent on the dissolution solvent used. Methanolic oil mixture inhibited all bacteria and fungi. Ethanol oil mixture inhibited the test bacteria and C. albicans while, the oil extract dissolved in Tween 80 solution showed no inhibitory activity on the test fungi. This study has shown that grape peels from Nigeria contain some antibiotic principles which may be explored for use in the treatment of certain diseases.
\end{abstract}

Keywords: Antimicrobial; Bacteria; Essential Oils; Fungi; GC-MS; Grape; Inhibition

\section{Introduction}

The increasing problems of antibiotic drug resistance by pathogenic organisms in the past few decades and recently have led to the continuous exploration of natural plant products for new antibiotic agents [1-4]. Many of these products are produced in plants as secondary metabolites and often used in plants for defense against microbial attack [4]. Essential oils are a class of such volatile compounds produced with inherent antimicrobial properties $[4,5]$. Essential oils (EOs) obtained from plants are a complex mixture of some compounds such as hydrocarbons, alcohols, esters, aldehydes and have been reported to exhibit inhibitory activities against a wide spectrum food spoilage microorganism [5].

Citrus is one of the most consumed fruits in the world

${ }^{*}$ Corresponding author. and contain a high amount of useful by-products which include essential oil [6]. It is mostly consumed fresh or used as raw materials for juice and wine [6]. The second largest world produced citrus fruit is grape; with an average of more than 60 million annual production.

Grapefruit (Citrus paradisi) belongs to the Citrus genus, a taxa of flowering plants in the family Rutaceae [5]. Grape is one of the citrus fruits cultivated and consumed in Nigeria [7]. The yield of grapefruit and oranges juice is about half of the fruit weight thereby generating a very high amount of waste annually [8,9]. Of the 36 metric tonnes of citrus waste produced annually, Florida generates 1.2 million which is sold as feed stock for cattle [10]. Nigeria generates about 0.3 million tonnes with potential to generate more annually [10]. This is one of the major agrowaste constituting a health and environmental menace in many streets and market places in 
Nigeria.

There are several reports on the essential oil composition of citrus peels, some of which includes; D-limonene, $\beta$-Myrcene, $\alpha$-pinene, $\beta$-pinene, $\gamma$-terpinene, $\alpha$-terpinolene, $\alpha$-Caryophyllene, copaene, $\beta$-phellandrene etc. [5,11-14]. Citrus fruits peels are also known to contain some antioxidants; flavonoids such as hesperidine, narirutin, naringin and eriocitrin, and also polyphenols such as caffeic acid, $p$-coumaric acid, ferulic acid and sinapinic acid $[8,15-17]$. The antimicrobial roles of flavonoids are well documented [18].

Essential oils and plant products have had a tremendous application in food, cosmetic and folk medicine and are continuously investigated for their antimicrobial activities $[6,19-26]$.

Antimicrobial effect of essential oils from Citrus paradisi peels from Turkey has been reported [5]. The essential oils composition of peels of Citrus reticulata L., $C$. paradisi, and Citrus Medica from Nigeria has been examined $[27,28]$. However, we have not found any information on the effects of essential oils of Citrus parasidi peels of Nigerian origin on a range of disease causing organisms. This study aimed to extract, characterize and determine the antimicrobial effects of Nigerian grape peels essential oil on selected clinical isolates.

\section{Materials and Methods}

\subsection{Plant Collection and Identification}

Matured grape fruits (Citrus paradisi) were bought from Onilegogoro market, Mushin, Lagos, Western-Nigeria.

The herbarium specimen of the plant was identified and authenticated by Mr. Tola Oyebanji in the Department of Botany, Faculty of Science, University of Lagos, Nigeria. The specimen were assigned voucher number LUH 5248 and deposited at the herbarium of the Department of Botany, Faculty of Science, University of Lagos.

\subsection{Essential Oil Extraction from Grape Peels}

The rind of the fresh citrus fruits was removed and $300 \mathrm{~g}$ was weighed and added into a warring blended cup containing $1 \mathrm{~L}$ of water. This was pulverized to puree in Marlex Exceller grinder (Mumbai, India). The rind puree was subjected to hydrodistillation in a 2 litres round bottom flask fitted to a Clevenger-type apparatus. The distillate obtained was dried over anhydrous sodium sulphate and stored in air tight amber-coloured bottle at $4{ }^{\circ} \mathrm{C}$ until it was needed for analysis.

The analysis of volatile essential oil components of grape peel was carried out on Agilent 7890 gas chromatograph (Agilent Technologies, Palo Alto, CA) coupled to an Agilent 5975C mass selective detector operating in electron impact mode (ionization voltage, $70 \mathrm{eV}$ ). A Chrompack CP-Wax $52 \mathrm{CB}$ capillary column $(30 \mathrm{~m}$ length $\times 0.32 \mathrm{~mm}$ internal diameter, film thickness 0.25 $\mu \mathrm{m})$ was used for the separation of the sample components.

A $1.0 \mu \mathrm{L}$ of the diluted oil sample was injected, using splitless mode the injector temperature was set at $250^{\circ} \mathrm{C}$ and helium was used as the carrier gas at a flow rate of 5 $\mathrm{ml} / \mathrm{min}$ and inlet pressure 12.936 p.s.i. The column oven temperature was gradually increased from $50^{\circ} \mathrm{C}$ to $240^{\circ} \mathrm{C}$ at a rate of $8^{\circ} \mathrm{C} / \mathrm{min}$, with a final hold time of $5 \mathrm{~min}$. The constituents of the oil were identified by using standard reference compounds and also by matching the mass spectra fragmentation pattern with National Institute of Standards and Technology (NIST) Mass Spectra Library stored in the GC-MS database.

\subsection{Bacterial and Fungal Cultures Collection}

The organisms used in this study were obtained from the Department of Medical Microbiology and Parasitology, Faculty of Basic Medical Sciences, College of Medicine, Idi araba, Lagos State, Nigeria. The cultures includes; Bacillus cereus, Enterococcus faecalis, Escherichia coli, E. coli ATCC 25292, Klebsellia pneumonia, Pseudococcus sp., Salmonella typhmurium, Shigella flexneri, Staphylococcus aureus, Staphylococus aureus ATCC 29213, Aspergillus niger, Candida albican and Penicillium chrysogenum. The bacteria cultures were maintained on MacConkey (Oxoid Ltd., Basingstoke, Hampshire, UK) agar slant at $37^{\circ} \mathrm{C}$ for $48 \mathrm{hrs}$ while fungal cultures were cultivated on Potato Dextrose Agar (Oxoid Ltd., Basingstoke, Hampshire, UK) slant at $25^{\circ} \mathrm{C}$ for 3 days. The organisms were then subcultured and preserved at $-20^{\circ} \mathrm{C}$ in sterile McCartney's bottles containing either MacConkey broth and 15\% sterile glycerol (bacteria) or Potato dextrose broth containing 15\% sterile glycerol (fungi).

\subsection{Antibacterial Screening of Extract}

The antimicrobial activity of citrus extract was determined by agar well diffusion method [29]. Each bacterial isolate preserved in $15 \%$ glycerol broth was subcultured on freshly prepared MacConkey agar (Oxoid Ltd., Basingstoke, Hampshire, UK) plate and incubated at $37^{\circ} \mathrm{C}$ for 24 hours. A bacterial colony was obtained with a sterile wire loop and emulsified in $5 \mathrm{ml}$ Mueller Hinton broth (Oxoid Ltd., Basingstoke, Hampshire, UK). The turbidity of the resulting mixtures was adjusted with sterile saline solution to 0.5 Mcfarland standard $(1.5 \times$ $10^{8}$ cells $\left.\cdot \mathrm{mL}^{-1}\right)$. Fresh Mueller Hinton agar plates were labeled and seeded with the test bacterial suspension using a sterile swab steak. These plates were allowed to stand for 15 minutes and agar punched out with sterile 
cork borer to create wells of $5 \mathrm{~mm}$ diameter. The essential oils were diluted to $8 \mu \mathrm{g} / \mathrm{ml}, 40 \mu \mathrm{g} / \mathrm{ml}$ and $80 \mu \mathrm{g} / \mathrm{ml}$ with methanol, ethanol or Tween $80(0.5 \% \mathrm{v} / \mathrm{v}) .100 \mu \mathrm{l}$ dilute essential oils of the different concentrations were dispensed into each agar well in a plate; plates were allowed to stand for 1 hour and then incubated at $37^{\circ} \mathrm{C}$ for 24 hours. A suspension of $0.5 \% \mathrm{w} / \mathrm{v}$ ciprofloxacin (Fidson Healthcare Ltd., Nigeria) was used as positive control while the solvent only was used as negative control. This experiment was performed in triplicate plates for each isolate per dissolution solvent. The diameter $(\mathrm{mm})$ of zone of inhibition was recorded for the different concentrations of oil samples.

\subsection{Antifungal Screening of Extract}

The fungal isolates were subcultured on Potato Dextrose Agar at $28^{\circ} \mathrm{C}$ for 3 - 5 days. Equally spaced wells were bored radially on sterile Potato Dextrose Agar plates using a $5 \mathrm{~mm}$ diameter sterile cork borer. $100 \mu$ dilute essential oils were added to the wells as described above. A $5 \mathrm{~mm}$ diameter fungal mycelial disc was placed at the center of the plate. $0.05 \% \mathrm{w} / \mathrm{v}$ Nystatin suspension (Mutual Pharmaceutical Company, Inc., Philadelphia, PA, USA) was used as positive control and the different dissolution solvent systems were used as negative control. Triplicate plates were used in each treatment. Plates were incubated at $28^{\circ} \mathrm{C}$ for 3 days. The zone of inhibition was recorded to the nearest $\mathrm{mm}$.

\subsection{Statistics}

Data obtained in this study were expressed as means \pm standard error (SE) for triplicate results. Mean difference in zones of inhibition between treatments and positive or negative control was examined using the One Way Analysis of Variance (ANOVA) and post hoc Tukey test. The effect of essential oil and its concentration on microbial growth inhibition among organisms was analyzed using a two factor ANOVA and significant interaction was subjected to Bonferroni post-test. The analyses were done at critical $p$ value of 0.05 using the GraphPad Prism version 5.00 for Windows (GraphPad Software, San Diego California USA).

\section{Results}

\subsection{Essential Oil Components}

The oil extracts obtained had a characteristic light yellow colour. The percentage yield and specific gravity was $0.79 \%$ and 0.883 respectively. The oil was soluble in ethanol, methanol and tween 80 solution. In this oil, 19 components were identified, this amount to $95.26 \%$ of the total volatile oil composition and represent six different groups of hydrocarbon namely; monoterpenes, oxygenated monoterpenes, aliphatic aldehydes, aliphatic hydrocarbons, sesquiterpenes and acid esters. The monoterpene hydrocarbons constituted the most dominant chemical group $(86.02 \%)$ and among which limonene is most predominant followed by $\beta$-myrcene, $\alpha$-pinene, $\beta$ phellandrene, 3-carene and nonane (Figure 1; Table 1). The oxygenated monoterpenes $(0.79 \%)$ were cis-linaloloxide and linalool. The aliphatic aldehydes $(2.79 \%)$ include octanal and decanal. Tridecane and tetradecane were the aliphatic hydrocarbons and account for $0.73 \%$ of the oil composition. The sesquiterpenes (3.89\%) which includes copaene, caryophyllene, $\alpha$-caryophyllene and $\delta$-cadinene was the second largest of the groups. The acid esters $(1.04 \%)$ found were methyl palmitate, methyl oleate and phthalate (Figure 1; Table 1).

Table 1. GC-MS profile of the components of Grape fruit peel (Citrus paradisi) essential oil obtained by Hydrodistillation.

\begin{tabular}{|c|c|c|c|}
\hline $\begin{array}{l}\text { Peak } \\
\text { No }\end{array}$ & Component & $\begin{array}{c}\text { Retention Time } \\
\text { (min) }\end{array}$ & $\begin{array}{c}\text { Concentration } \\
(\%)\end{array}$ \\
\hline 1 & Nonane $^{\mathrm{a}}$ & 5.707 & 0.20 \\
\hline 2 & $\alpha$-Pinene ${ }^{\mathbf{a}}$ & 6.182 & 2.11 \\
\hline 3 & $\beta$-Phellandrene ${ }^{\mathbf{a}}$ & 6.709 & 1.18 \\
\hline 4 & $\beta$-Myrcene ${ }^{\mathrm{a}}$ & 6.983 & 7.25 \\
\hline 5 & Octanal $^{\mathbf{c}}$ & 7.144 & 1.68 \\
\hline 6 & D-limonene ${ }^{\mathbf{a}}$ & 7.659 & 75.07 \\
\hline 7 & 3-Carene ${ }^{a}$ & 7.836 & 0.21 \\
\hline 8 & Cis-Linaloloxide $^{\mathbf{b}}$ & 7.968 & 0.31 \\
\hline 9 & Linalool $^{\mathbf{b}}$ & 8.247 & 0.48 \\
\hline 10 & Decanal $^{\mathbf{c}}$ & 9.307 & 1.11 \\
\hline 11 & Tridecane $^{\mathbf{d}}$ & 10.18 & 0.26 \\
\hline 12 & Copaene $^{e}$ & 10.983 & 0.82 \\
\hline 13 & Tetradecane $^{\mathbf{d}}$ & 11.075 & 0.47 \\
\hline 14 & Caryophyllene $^{\mathbf{e}}$ & 11.395 & 1.88 \\
\hline 15 & $\alpha$-Caryophyllene $\mathrm{e}^{\mathrm{e}}$ & 11.687 & 0.30 \\
\hline 16 & $\delta$-Cadinene $e^{\mathrm{e}}$ & 12.236 & 0.89 \\
\hline 17 & Methyl palmitate ${ }^{\mathrm{f}}$ & 16.505 & 0.31 \\
\hline 18 & Methyl oleate $^{\mathrm{f}}$ & 18.410 & 0.19 \\
\hline \multirow[t]{2}{*}{19} & Phthalate ${ }^{\mathrm{f}}$ & 22.090 & 0.54 \\
\hline & Total identified (\%) & & 95.26 \\
\hline \multirow[t]{3}{*}{---} & Other ${ }^{\mathrm{g}}$ & Varies & 4.74 \\
\hline & Yield (\%) & & 0.79 \\
\hline & Specific gravity & & 0.883 \\
\hline
\end{tabular}

${ }^{\mathrm{a}}$ Monoterpene, ${ }^{\mathrm{b}}$ Oxygenated monoterpene, ${ }^{\mathrm{c}}$ Aliphatic Aldehyde, ${ }^{\mathrm{d}}$ Aliphatic hydrocarbon, ${ }^{\text {e }}$ Sesquiterpene, ${ }^{\mathrm{f}}$ Acid ester, and ${ }^{\mathrm{g}}$ Other unidentified hydrocarbons. 


\subsection{Antibacterial Activities of the Oil Extract Solvent Mix}

The effect of the methonilic-oil and its concentration on the overall growth inhibition among bacterial strains were analysed by two factor ANOVA and Bonferroni post-test. Results indicate that dilute Citrus paradisi fruit peel essential oil in methanol significantly affected the overall inhibition among the bacterial strains $\left(F_{9,18}=\right.$ 44.70, $P<0001)$, and this inhibition was significantly $\left(F_{2,18}=18.27, P<0.0001\right)$ affected by the concentration of the oil used (Table 2).

The oil at all concentrations significantly inhibited the

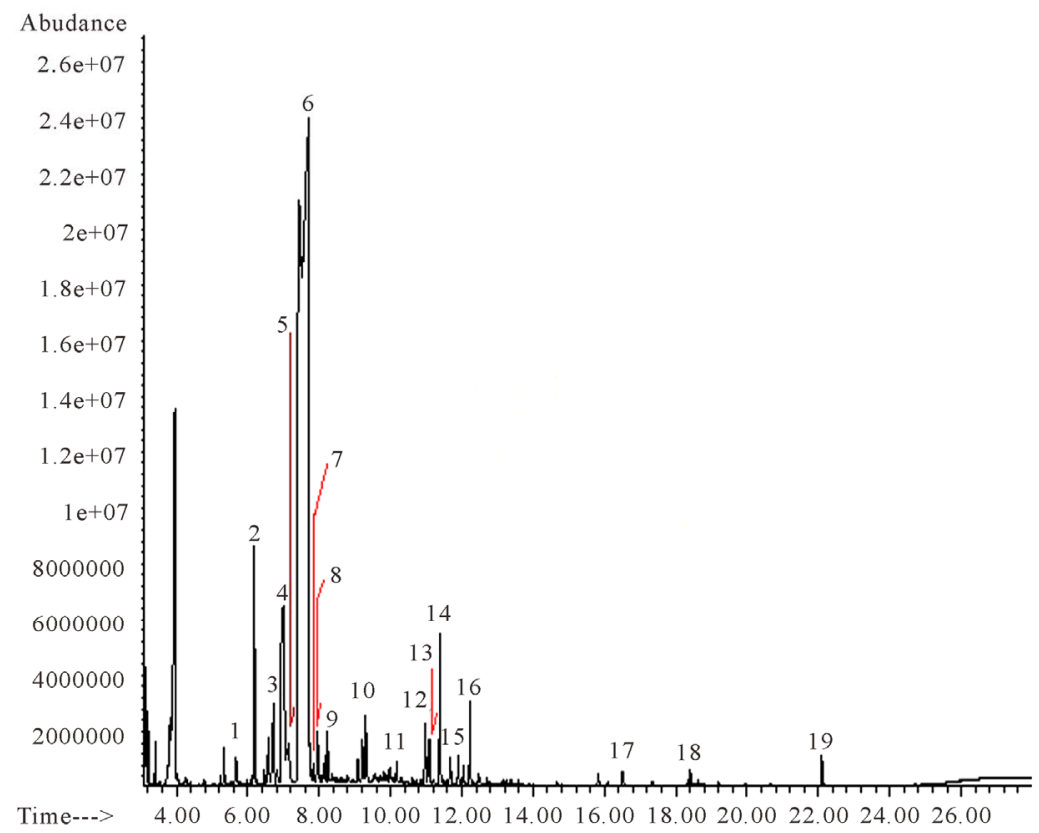

Figure 1. GC/MS Chromatogram of essential oil of Citrus paradisi (grape fruit). Number corresponds to (1) Nonane, (2) $\alpha$-Pinene, (3) $\beta$-Phellandrene, (4) $\beta$-Myrcene, (5) Octanal, (6) D-limonene, (7) 3-Carene, (8) Cis Linaloloxide, (9) Linalool, (10) Decanal, (11) Tridecane, (12) Copaene, (13) Tetradecane, (14) Caryophyllene, (15) $\alpha$-Caryophyllene, (16) $\delta$-Cadinene, (17) Methyl palmitate, (18) Methyl oleate, (19) Phthalate.

${ }^{1}$ Table 2. Zone of inhibition (mm) of different bacterial pathogen in methanolic oil extract of Citrus paradisi peels.

\begin{tabular}{|c|c|c|c|c|c|}
\hline \multirow{2}{*}{$\begin{array}{c}\text { Test bacteria } \\
\text { Gram positive }\end{array}$} & \multirow{2}{*}{$\begin{array}{c}\text { Ciprofloxacin } \\
\text { (Positive control) }\end{array}$} & \multirow{2}{*}{ Met $(-)$} & \multicolumn{3}{|c|}{ grape peels oil extracts in methanol } \\
\hline & & & $80 \mu \mathrm{g} / \mathrm{ml}$ & $40 \mu \mathrm{g} / \mathrm{ml}$ & $8 \mu \mathrm{g} / \mathrm{ml}$ \\
\hline B. cereus & $23.00 \pm 2.08$ & NI & $32.67 \pm 1.20^{\mathrm{a}, \mathrm{d}, \mathrm{e}}$ & $31.67 \pm 0.33^{\mathrm{a}, \mathrm{e}}$ & $30.33 \pm 0.33^{\mathrm{a}}$ \\
\hline E. faecalis & $18.00 \pm 5.00$ & NI & $12.00 \pm 2.00^{\mathrm{b}, \mathrm{c}, \mathrm{f}}$ & $7.33 \pm 0.67^{\mathrm{b}, \mathrm{c}}$ & $6.00 \pm 3.06^{\mathrm{b}, \mathrm{c}}$ \\
\hline Pseudococcus sp. & $30.33 \pm 2.33$ & NI & $11.67 \pm 0.88^{\mathrm{a}, \mathrm{b}, \mathrm{f}}$ & $10.00 \pm 2.00^{\mathrm{c}, \mathrm{b}, \mathrm{f}}$ & $9.00 \pm 0.57^{\mathrm{c}, \mathrm{b}, \mathrm{f}}$ \\
\hline Staph. aureus & $24.00 \pm 1.15$ & NI & $25.33 \pm 2.18^{\mathrm{d}, \mathrm{a}, \mathrm{e}, \mathrm{i}}$ & $23.00 \pm 0.58^{\mathrm{d}, \mathrm{e}, \mathrm{i}}$ & $17.00 \pm 1.00^{\mathrm{d}, \mathrm{e}, \mathrm{i}}$ \\
\hline $\begin{array}{c}\text { Staph. aureus ATCC } \\
29213\end{array}$ & $24.60 \pm 1.73$ & NI & $27.33 \pm 3.71^{\mathrm{e}, \mathrm{ad}, \mathrm{d}, \mathrm{i}}$ & $26.00 \pm 2.52^{\mathrm{e}, \mathrm{a}, \mathrm{d}, \mathrm{i}}$ & $19.67 \pm 5.84^{\mathrm{e}, \mathrm{d}, \mathrm{i}}$ \\
\hline \multicolumn{6}{|l|}{ Gram negative } \\
\hline E. coli & $22.33 \pm 1.15$ & NI & $12.67 \pm 0.67^{\mathrm{f}, \mathrm{b}, \mathrm{c}, \mathrm{g}}$ & $11.33 \pm 2.02^{\mathrm{f}, \mathrm{c}, \mathrm{g}}$ & $8.67 \pm 1.76^{\mathrm{f}, \mathrm{c}, \mathrm{g}}$ \\
\hline E. coli ATCC 25292 & $32.00 \pm 0.88$ & NI & $14.00 \pm 2.00^{\mathrm{g}, \mathrm{fh}}$ & $12.33 \pm 1.85^{\mathrm{g}, \mathrm{f,h}}$ & $10.33 \pm 0.33^{\mathrm{g}, \mathrm{f}, \mathrm{h}, \mathrm{i}}$ \\
\hline K. pneumonia & NI & $\mathrm{NI}^{+}$ & $12.00 \pm 1.53^{\mathrm{h}, \mathrm{g}}$ & $10.67 \pm 2.67^{\mathrm{h}, \mathrm{g}}$ & $10.33 \pm 2.33^{\mathrm{h}, \mathrm{g}}$ \\
\hline S. typhimurium & $33.00 \pm 1.00$ & NI & $24.67 \pm 0.67^{\mathrm{i}, \mathrm{d}, \mathrm{e}, \mathrm{j}}$ & $24.00 \pm 0.67^{\mathrm{i}, \mathrm{d}, \mathrm{e}, \mathrm{j}}$ & $20.00 \pm 1.15^{\mathrm{i}, \mathrm{d}, \mathrm{e}}$ \\
\hline S. flexneri & $30.67 \pm 0.88$ & NI & $24.33 \pm 1.20^{\mathrm{i}, \mathrm{i}}$ & $23.67 \pm 0.88^{\mathrm{j}, \mathrm{i}}$ & $12.00 \pm 1.53^{\mathrm{j}, \mathrm{g}}$ \\
\hline
\end{tabular}

${ }^{1}$ Observations are expressed as mean \pm standard error of mean, $\mathrm{n}=3$. Values exclude diameter of agar well ( $\left.5 \mathrm{~mm}\right)$. A value in a row with superscript " + " is not significantly different from positive control $(P>0.05)$. Means in the same column with different superscripts are significantly different $(P<0.05)$ according to Bonferroni posttests. NI $=$ Not inhibition. Met $(-)=$ Methanol (negative control). 
growth of all the bacterial strains $(P<0.05)$ compared to the negative control (Table 2).

The inhibition was highest with $B$. cereus and $S$. aureus ATCC 21293, and least with E. faecalis.

Inhibition of each isolate was highest with positive control antibiotics (Ciprofloxacin) except in $S$. aureus ATCC 21293 and B. cereus which were higher than Ciproflaxin treatment.

Similarly, ethanolic oil extract significantly reduced the growth among isolates $\left(F_{7,14}=12.87, P<0.0001\right)$ and the inhibition was significantly affected by the oil concentration $\left(F_{2,14}=13.97, P=0.0005\right)$. The oil in etha- nol significantly inhibited the growth of all the test bacteria except $E$. coli when compared to negative control ( $P$ $<0.05$ ) (Table 3). B. cereus was most sensitive while $E$. coli ATCC 25292 was not sensitive to the extract. Ciprofloxacin treatments resulted in significantly higher growth inhibition compared to the all test concentrations of extract in each isolate.

Only a few organisms which included $S$. aureus ATCC 29213, E. coli, E. coli ATCC 25292, Salmonella typhi, and Shigella flexneri were sensitive to tween 80 oil extracts (Table 4). The inhibition of E. coli was significantly more than other organisms $(P<0.05)$.

${ }^{1}$ Table 3. Zone of inhibition ( $\mathrm{mm}$ ) of different bacterial pathogen in ethanolic oil extract of Citrus paradisi peels.

\begin{tabular}{|c|c|c|c|c|c|}
\hline \multirow{2}{*}{$\begin{array}{c}\text { Test bacteria } \\
\text { Gram positive }\end{array}$} & \multirow{2}{*}{$\begin{array}{c}\text { Ciprofloxacin } \\
\text { (Positive control) }\end{array}$} & \multirow{2}{*}{ Ethl $(-)$} & \multicolumn{3}{|c|}{ grape peels oil extracts in ethanol } \\
\hline & & & $80 \mu \mathrm{g} / \mathrm{ml}$ & $40 \mu \mathrm{g} / \mathrm{ml}$ & $8 \mu \mathrm{g} / \mathrm{ml}$ \\
\hline B. cereus & $24.00 \pm 1.15$ & NI & $20.00 \pm 0.00^{+, \mathrm{a}}$ & $19.67 \pm 0.73^{+, \mathrm{a}}$ & $11.00 \pm 1.00^{\mathrm{a}, \mathrm{d}, \mathrm{b}}$ \\
\hline E. faecalis & $20.00 \pm 3.29$ & NI & NI & $8.00 \pm 1.15^{\mathrm{b}, \mathrm{i}}$ & NI \\
\hline Pseudococcus sp. & $30.33 \pm 6.67$ & NI & $12.67 \pm 3.18^{\mathrm{b}, \mathrm{cd}, \mathrm{e}, \mathrm{g}}$ & $11.00 \pm 1.67^{\mathrm{c}, \mathrm{de}, \mathrm{ef}, \mathrm{h}}$ & $9.33 \pm 0.67^{\mathrm{b}, \mathrm{a}, \mathrm{c}, \mathrm{d}, \mathrm{e}, \mathrm{f}}$ \\
\hline Staph. aureus & $24.60 \pm 5.13$ & NI & $13.00 \pm 3.51^{\mathrm{c}, \mathrm{b}, \mathrm{e}, \mathrm{g}}$ & $11.33 \pm 0.67^{\mathrm{d}, \mathrm{c}, \mathrm{e}, \mathrm{h}}$ & $10.00 \pm 1.08^{\mathrm{c}, \mathrm{a}, \mathrm{d}, \mathrm{e}}$ \\
\hline $\begin{array}{c}\text { Staph. aureus ATCC } \\
29213\end{array}$ & $25.00 \pm 0.57$ & NI & $10.67 \pm 2.19^{\mathrm{d}, \mathrm{b}, \mathrm{c}, \mathrm{e}}$ & $10.00 \pm 0.33^{\mathrm{e}, \mathrm{c}, \mathrm{d}, \mathrm{h}}$ & $9.67 \pm 0.70^{\mathrm{d}, \mathrm{b}, \mathrm{c}, \mathrm{e}}$ \\
\hline \multicolumn{6}{|l|}{ Gram negative } \\
\hline E. coli & $22.33 \pm 1.20$ & NI & $12.67 \pm 2.33^{\mathrm{e}, \mathrm{b}, \mathrm{c}, \mathrm{g}}$ & $12.00 \pm 1.15^{\mathrm{fcc,d,e,h}}$ & $11.33 \pm 1.33^{\mathrm{e}, \mathrm{b}, \mathrm{c}, \mathrm{d}}$ \\
\hline E. coli ATCC 25292 & $32.00 \pm 1.15$ & NI & NI & NI & NI \\
\hline K. pneumonia & NI & $\mathrm{NI}^{+}$ & $8.67 \pm 0.88^{\mathrm{f,h}}$ & $6.33 \pm 0.33^{\mathrm{g}, \mathrm{i}}$ & $\mathrm{NI}^{+}$ \\
\hline S. typhimurium & $33.33 \pm 0.88$ & NI & $13.67 \pm 0.67^{\mathrm{g}, \mathrm{b}, \mathrm{c}, \mathrm{d}, \mathrm{e}}$ & $11.67 \pm 0.67^{\mathrm{h}, \mathrm{cd}, \mathrm{e}, \mathrm{f}}$ & $8.00 \pm 0.58^{\mathrm{f}, \mathrm{b}, \mathrm{c}, \mathrm{d}}$ \\
\hline S. flexneri & $30.67 \pm 1.76$ & NI & $8.00 \pm 1.15^{\mathrm{h}, \mathrm{f}}$ & $7.00 \pm 2.33^{\mathrm{i}, \mathrm{b}, \mathrm{g}}$ & $4.04 \pm 1.15^{\mathrm{g}}$ \\
\hline
\end{tabular}

${ }^{1}$ Observations are expressed as mean \pm standard error of mean, $\mathrm{n}=3$. Values exclude diameter of agar well (5 mm). A value in a row with superscript " + " is not significantly different from positive control $(P>0.05)$. Means in the same column with different superscripts are significantly different $(P<0.05)$ according to Bonferroni posttests. NI = Not inhibition. Ethl $(-)=$ ethanol (negative control).

${ }^{1}$ Table 4. Zone of inhibition (mm) of different bacterial pathogen in $0.5 \%$ Tween 80 -oil extract of Citrus paradisi peels.

\begin{tabular}{|c|c|c|c|c|c|}
\hline \multirow{2}{*}{$\begin{array}{c}\text { Test bacteria } \\
\text { Gram positive }\end{array}$} & \multirow{2}{*}{$\begin{array}{c}\text { Ciprofloxacin } \\
\text { (Positive control) }\end{array}$} & \multirow{2}{*}{ Tw $80(-)$} & \multicolumn{3}{|c|}{ grape peels oil extracts in $0.5 \%$ Tween 80} \\
\hline & & & $80 \mu \mathrm{g} / \mathrm{ml}$ & $40 \mu \mathrm{g} / \mathrm{ml}$ & $8 \mu \mathrm{g} / \mathrm{ml}$ \\
\hline B. cereus & $22.33 \pm 0.33$ & NI & NI & NI & NI \\
\hline E. faecalis & $18.00 \pm 0.00$ & NI & NI & NI & NI \\
\hline Pseudococcus sp. & $29.67 \pm 0.67$ & NI & NI & NI & NI \\
\hline Staph. aureus & $24.80 \pm 0.88$ & NI & NI & NI & NI \\
\hline $\begin{array}{c}\text { Staph. aureus ATCC } \\
29213\end{array}$ & $22.67 \pm 1.33$ & NI & $10.34 \pm 0.42^{\mathrm{a}, \mathrm{d}}$ & $9.67 \pm 0.33^{\mathrm{a}}$ & $9.64 \pm 0.33^{\mathrm{a}}$ \\
\hline \multicolumn{6}{|l|}{ Gram negative } \\
\hline E. coli & $21.67 \pm 3.33$ & NI & $20.67 \pm 1.45^{+, \mathrm{b}}$ & $18.00 \pm 2.17^{+, \mathrm{b}}$ & $18.00 \pm 3.51^{+, \mathrm{t}}$ \\
\hline E. coli ATCC 25292 & $32.00 \pm 1.33$ & NI & $6.33 \pm 0.33^{\mathrm{c}, \mathrm{e}}$ & $5.33 \pm 1.45^{\mathrm{c}, \mathrm{d}}$ & NI \\
\hline K. pneumonia & NI & NI & NI & NI & NI \\
\hline S. typhimurium & $33.33 \pm 1.33$ & NI & $10.33 \pm 0.33^{\mathrm{d}, \mathrm{a}}$ & $6.67 \pm 0.67^{\mathrm{d}, \mathrm{c}}$ & NI \\
\hline S. flexneri & $30.67 \pm 2.33$ & NI & $5.33 \pm 2.90^{\mathrm{e}, \mathrm{c}}$ & $4.00 \pm 2.31^{\mathrm{e}}$ & NI \\
\hline
\end{tabular}

${ }^{1}$ Observations are expressed as mean \pm standard error of mean, $\mathrm{n}=3$. Values exclude diameter of agar well (5 mm). A value in a row with superscript " + " is not significantly different from positive control $(P>0.05)$. Means in the same column with different superscripts are significantly different $(P<0.05)$ according to Bonferroni posttests. NI $=$ Not inhibition. Tw $80(-)=$ Tween 80 (negative control). 


\subsection{Antifungal Activities of the Oil Extract Solvent Mix}

A two ANOVA indicate that the methanolic oil extract showed significant effect on the overall fungal growth inhibition $\left(F_{2,4}=200.76, P<0.0001\right)$, however, the concentration of the oil used showed no significant overall effect on inhibition among fungi $\left(F_{2,4}=3.56, P=\right.$ $0.1293)$. The oil significantly inhibited the isolates compared to negative control $(P<0.05)$ although, the inhibition was significantly lower to Nystatin treated fungi except $P$. chrysogenum $(P<0.05)$ (Table 5). The sensitivity of $P$. chrysogenum was significantly $(P<0.05)$ higher than $C$. albican and A. niger. Moreso, ethanolic oil extract only inhibited $C$. albican with diameter of zone of inhibition $16.67 \pm 0.67,13.33 \pm 1.33$ and $12.33 \pm$ 0.88 at oil concentrations $80 \mu \mathrm{g} / \mathrm{ml}, 40 \mu \mathrm{g} / \mathrm{ml}$ and 8 $\mu \mathrm{g} / \mathrm{ml}$ respectively. Methanolic-Nystatin treatment showed inhibitory property on the test fungi: C. albicans; $31.33 \pm$ 0.67 , A. niger; $22.33 \pm 1.20$ and P. chrysogenum; $26.98 \pm$ 1.08. The essential oil in tween 80 did not show inhibitory activity except the positive control treatments $C$. albicans; $30.67 \pm 0.67$, A. niger; $19.67 \pm 2.73$, P. chrysogenum; $26.67 \pm 0.88$.

\section{Discussion}

The major components of the essential oil of grape peel in this study include $\mathrm{D}$-limonene, $\beta$-myrcene, $\alpha$-pinene, $\alpha$-caryophyllene, octanal, $\beta$-phellandrene and decanal. The minor components each were less than $1 \%$ of the oil composition and they include $\delta$-cadinene, copaene, phthalate, linalool, tetradecane, cis-linaloloxide, methyl palmitate, $\alpha$-Caryophyllene, tridecane, 3-carene, methyl oleate and nonane. These components as well as D-limonene being the predominant have been previously reported in other studies on grape and other citrus peel oils $[5,11,13]$. The monoterpenes followed by the sesquiterpenes were the major group of compounds in the oil and thus corroborate previous findings on components of citrus peel essential oils [5,11,13,30-31]. The percentage oil yield was higher than some previous reports on grape peel oil [5, $32]$. The was variation in the oil yield and the amount of the essential oil components obtained in this study compared to other literatures $[5,11,13]$ and this may be due to factors such as the vegetative age, origin, specie of the fruit used as well as the extraction procedure employed [5,11-12,33].

The oil extract of grape peels inhibited all the test bacterial and fungal strains. Some of these bacterial strains have also been previously studied and found to be sensitive to grape oil. For example Dabbah et al. [34] showed that the oil of grape peels and other citrus fruits peel as well as their derivatives inhibited Escherichia coli, Salmonella sp., Staphylococcus aureus and Pseudomonas sp.

The oil of grape peels have also been reported to inhibit Staphylococcus aureus ATCC 25923, Enterococcus faecalis ATCC 29212, Escherichia coli ATCC 35218, Salmonella typhimurium ATCC 14028, Serratia marcescens ATCC 8100 and Proteus vulgaris ATCC 13315 except Pseudomonas aeruginosa ATCC 27853 [5]. Kirbaslar et al. [13] also showed that the oil of grape peels as well as some citrus fruits peel exhibited a broad spectrum inhibitory activity on some bacterial cultures which includes; S. aureus ATCC 6538, B. cereus ATCC 7064, M. smegmatis CCM 2067, L. monocytogenes ATCC 15313, M. luteus La 2971, E. coli ATCC 11230, K. pneumoniae UC57, P. aeruginosa ATCC 27853, P. vulgaris ATCC 8427 and the yeast cultures C. albicans ATCC 10231, K. fragilis NRRL 2415, R. rubra DSM 70403, D. hansenii DSM 70238 and H. guilliermondii DSM 3432.

The essential oils also inhibited A. niger and Penicillium chrysogenum in this study. This corroborate the studies by Caccioni et al. [35] and Viuda-Martos et al. [36] whose work showed that essential oils from grape peels was able to inhibit Aspergillus niger, Aspergillus flavus, Penicillium chrysogenum and Penicillium verrucosum.

The major component of the oil was D-limonene and probably the antibacterial and antifungal property of the oils. D-limonene has been reported to inhibit E. coli, Staph. Aureus, Salmonella sp. and Pseudomonas sp. [34]. It has also been shown to inhibit some yeast species; Sachharomyces elipsoideus, Wilia hansenula and Oidium lactis [37].

${ }^{1}$ Table 5. Zone of inhibition ( $\mathrm{mm}$ ) of different fungal strains in methanolic oil extracts of Citrus paradisi peels.

\begin{tabular}{cccccc}
\hline Test fungi & \multirow{2}{*}{$\begin{array}{c}\text { Nystatin } \\
\text { (Positive control) }\end{array}$} & Met $(-)$ & \multicolumn{3}{c}{ grape peels oil extracts in methanol } \\
\cline { 4 - 6 } & $31.33 \pm 0.67$ & NI & $11.00 \pm 0.57^{\mathrm{a}}$ & $10.02 \pm 0.67^{\mathrm{a}}$ & $9.60 \pm 0.67^{\mathrm{a}}$ \\
C. albican & $22.33 \pm 1.76$ & NI & $6.00 \pm 0.00^{\mathrm{b}}$ & $4.67 \pm 2.40^{\mathrm{b}}$ & $4.67 \pm 2.40^{\mathrm{b}}$ \\
A. niger & $26.33 \pm 0.88$ & NI & $25.00 \pm 0.57^{+, \mathrm{c}}$ & $24.00 \pm 2.00^{+, \mathrm{c}}$ & $20.33 \pm 2.33^{\mathrm{c}}$ \\
\hline
\end{tabular}

${ }^{1}$ Observations are expressed as mean \pm standard error of mean, $\mathrm{n}=3$. Values exclude diameter of agar well ( $\left.5 \mathrm{~mm}\right)$. A value in a row with superscript " + " is not significantly different from positive control $(P>0.05)$. Means in the same column with different superscripts are significantly different $(P<0.05)$ according to Bonferroni posttests. NI $=$ Not inhibition. Met $(-)=$ Methanol (negative control). 
Unal et al. [38] also demonstrated the antifungal and inhibitory effect of D-limonene on a variety of yeast strains. The inhibitory activity of the essential oil may be a cumulative effect of D-limonene and some other unidentified components or flavonoids and phenolic compound present. For instance, flavonoids are known as antimicrobial agents [18] and some phenolic compounds have be shown to inhibit the growth of Staphylococcus aureus [39].

The oil extract was also able to inhibit the fungi tested depending on the dissolution solvent.

The inhibition was dependent on the type of dissolution solvent used. Inhibition was most favoured when oil was dissolved in methanol, followed by ethanol and least in tween 80 solution. The essential oil in methanol showed the highest inhibition against $B$. cereus compared to other isolate. Also, the inhibition of either B. cereus or $S$. aureus was significantly higher to the positive control antibiotics (ciprofloxacin). Uysal et al. [5] also reported that $S$. aureus was the most sensitive bacterial strain to oil of grape peels when compared to E. faecalis, Staphylococcus epidermidis, E. coli, Pseudomonas aeruginosa, S. typhimurium, Serratia marcescens and Proteus vulgaris. The inhibition of $S$. aureus and E. coli by grape oil was higher than the positive control antibiotics [5].

Only the strains of E. coli, E. coli 25292 and Staph aureus ATCC 29213 were inhibited by Tween 80 oil extract. There was no fungal inhibition recorded in the tween 80 oil extract. Studies have shown that Tween 80 was able to either inhibit or enhance the growth of microorganisms and these depend on the concentration of the tween solution. Boxtel et al. [40] reported that the growth of Mycobecterium paratuberculosis was enhanced at concentrations $0.1 \%-1.0 \%(\mathrm{w} / \mathrm{v})$ Tween 80 and suppressed at concentrations $0.01 \%-0.1 \%(\mathrm{w} / \mathrm{v})$ Tween 80. Moreso, the concentration of Tween 80 solution used in this study was $0.5 \%$ and could be responsible for growth enhancement of the test organisms or antagonistic effect of the oil extracts. Li et al. [41] also showed that Tween 80 solution could reverse the inhibitory effects of bile salt and its derivatives on the growth of Lactobacillus acidophilus and the production of Cis-9, trans-11 conjugated linoleic acid $(c 9, t 11$ CLA) by this organism.

\section{Conclusion}

This study has shown that the oil extract of grape peels from Nigeria contains some useful potential antibiotic principles that are inhibitory to a broad spectrum of clinical isolates. Thus, it may be considered as a natural source of antimicrobials for therapeutic purposes.

\section{Acknowledgements}

The authors are grateful to Mrs Olayemisi Adenike Ala- desokun for providing us the clinical isolates and $\mathrm{Mr}$. Tola Oyebanji for the identification service.

\section{REFERENCES}

[1] G. Ayoola, F. Lawore, T. Adelowotan, I. Aibinu, E. Adenipekun, H. Coker and T. Odugbemi, "Chemical Analysis and Antimicrobial Activity of the Essential Oil of Syzigium aromaticum (clove)," African Journal of Microbiology Research, Vol. 2, 2008, pp. 162-166.

[2] N. Belmekki, N. Bendimerad, C. Bekhechi and X. Fernandez, "Chemical Analysis and Antimicrobial Activity of Teucrium polium L. Essential Oil from Western Algeria," Journal of Medicinal Plants Research, Vol. 7, No. 14, 2013, pp. 897-902.

[3] A. A. Dahpour, P. Rahdari and Z. Sobati, "Chemical Composition of Essential Oil, Antibacterial Activity and Brine Shrimp Lethality of Ethanol Extracts from Sedum pallidum," Journal of Medicinal Plants Research, Vol. 6, No. 16, 2012, pp. 3105-3109.

[4] L. Shittu, M. Bankole, T. Ahmed, M. Bankole, R. Shittu, C. Saalu and O. Ashiru, "Antibacterial and Antifungal Activities of Essential Oils of Crude Extracts of Sesame Radiatum against Some Common Pathogenic Micro-Organisms" Iranian Journal of Pharmacology \& Therapeutics (IJPT), Vol. 6, No. 2, 2008, pp. 165-170.

[5] B. Uysal, F. Sozmen, O. Aktas, B. S. Oksal and E. O. Kose, "Essential Oil Composition and Antibacterial Activity of the Grapefruit (Citrus paradisi L.) Peel Essential Oils Obtained by Solvent-Free Microwave Extraction: Comparison with Hydrodistillation," International Journal of Food Science \& Technology, Vol. 46, No. 7, 2011, pp. 1455-1461. doi:10.1111/j.1365-2621.2011.02640.x

[6] A. Schieber, F. Stintzing and R. Carle, "By-Products of Plant Food Processing as a Source of Functional Compounds-Recent Developments," Trends in Food Science \& Technology, Vol. 12, No. 11, 2001, pp. 401-413. doi:10.1016/S0924-2244(02)00012-2

[7] O. O. Odubanjo and A. Y. Sangodoyin, "An Improved Understanding of Current Agricultural and Industrial Waste Management Techniques in Southwestern Nigeria Using Field Evidence," The Journal of Urban and Environmental Research, Vol. 3, No. 1, 2002, pp. 67-75.

[8] A. Bocco, M. E. Cuvelier, H. Richard and C. Berset, "Antioxidant Activity and Phenolic Composition of Citrus Peel and Seed Extracts," Journal of Agricultural and Food Chemistry, Vol. 46, 1998, pp. 2123-2129. doi:10.1021/jf9709562

[9] H. Bovili, "Orange: Source of Natural Compounds," Aromes Ingred Addit, Vol. 7, 1996, pp. 41-42.

[10] T. I. N. Ezejiofor, V. Eke, R. Okechukwu, R. Nwoguikpe and C. Duru, "Waste to Wealth: Industrial Raw Materials Potential of Peels of Nigerian Sweet Orange (Citrus sinensis)," African Journal of Biotechnology, Vol. 10, No. 33, 2011, pp. 6257-6264.

[11] S. Bourgou, F. Z. Rahali, I. Ourghemmi and M. S. Tounsi, "Changes of Peel Essential Oil Composition of Four Tunisian Citrus during Fruit Maturation," The Scientific 
World Journal, 2012. doi:10.1100/2012/528593

[12] S. Droby, A. Eick, D. Macarisin, L. Cohen, G. Rafael, R. Stange, G. McColum, N. Dudai, A. Nasser and M. Wisniewski, "Role of Citrus Volatiles in Host Recognition, Germination and Growth of Penicillium digitatum and Penicillium italicum," Postharvest Biology and Technology, Vol. 49, No. 3, 2008, pp. 386-396. doi:10.1016/j.postharvbio.2008.01.016

[13] F. G. Kirbaşlar, A. Tavman, B. Dülger and G. Türker, "Antimicrobial Activity of Turkish Citrus Peel Oils," $\mathrm{Pa}$ kistan Journal of Botany, Vol. 41, No. 6, 2009, pp. 32073212.

[14] S. R. Fuselli, S. B. G. de la Rosa, M. J. Eguaras and R. Fritz, "Chemical Composition and Antimicrobial Activity of Citrus Essences on Honeybee Bacterial Pathogen $\mathrm{Pa}$ enibacillus larvae, the Causal Agent of American Foulbrood," World Journal of Microbiology and Biotechnology, Vol. 24, No. 10, 2008, pp. 2067-2072. doi:10.1007/s11274-008-9711-9

[15] K. Ghasemi, Y. Ghasemi and M. A. Ebrahimzadeh, "Antioxidant Activity, Phenol and Flavonoid Contents of 13 Citrus Species Peels and Tissues," Pakistan Journal of Pharmaceutical Sciences, Vol. 22, No. 3, 2009, pp. 277281.

[16] J. Fernández-López, J. Fernández-Ginés, L. Aleson-Carbonell, E. Sendra, E. Sayas-Barberá and J. Pérez-Alvarez, "Application of Functional Citrus By-Products to Meat Products," Trends in Food Science \& Technology, Vol. 15, 2004, pp. 176-185. doi:10.1016/j.tifs.2003.08.007

[17] S. Gorinstein, O. Martín-Belloso, Y. S. Park, R. Haruenkit, A. Lojek, M. Ĉíž, A. Caspi, I. Libman and S. Trakhtenberg, "Comparison of Some Biochemical Characteristics of Different Citrus Fruits," Food Chemistry, Vol. 74, No. 3, 2004, pp. 309-315. doi:10.1016/S0308-8146(01)00157-1

[18] T. Cushnie and A. J. Lamb, "Antimicrobial Activity of Flavonoids," International Journal of Antimicrobial Agents, Vol. 26, No. 5, 2005, pp. 343-356. doi:10.1016/j.ijantimicag.2005.09.002

[19] H. Girish and S. Satish, "Antibacterial Activity of Important Medicinal Plants on Human Pathogenic Bacteria: A Comparative Analysis," World Applied Sciences Journal, Vol. 5, No. 3, 2008, pp. 267-271.

[20] D. Kalemba and A. Kunicka, "Antibacterial and Antifungal Properties of Essential Oils," Current Medicinal Chemistry, Vol. 10, No. 10, 2003, pp. 813-829. doi:10.2174/0929867033457719

[21] S. Mousavi, S. Mirzargar, H. E. Z. Mousavi, R. O. Baigi, A. Khosravi, A. Bahonar and M. Ahmadi, "Evaluation of Antifungal Activity of New Combined Essential Oils in Comparison with Malachite Green on Hatching Rate in Rainbow Trout (Oncorhynchus mykiss) Eggs," Journal of Fisheries and Aquatic Science, Vol. 4, No. 2, 2009, pp. 103-110. doi:10.3923/jfas.2009.103.110

[22] S. M. Mousavi, G. Wilson, D. Raftos, S. S. Mirzargar and R. Omidbaigi, "Antibacterial Activities of a New Combination of Essential Oils against Marine Bacteria," Aquaculture International, Vol. 19, No. 1, 2011, pp. 205214. doi:10.1007/s10499-010-9354-3
[23] W. Ramadan, B. Mourad, S. Ibrahim and F. Sonbol, "Oil of Bitter Orange: New Topical Antifungal Agent," International Journal of Dermatology, Vol. 35, No. 6, 1996, pp. 448-449. doi:10.1111/j.1365-4362.1996.tb03032.x

[24] F. Haddouchi, T. M. Chaouche, Y. Zaouali, R. Ksouri, A. Attou and A. Benmansour, "Chemical Composition and Antimicrobial Activity of the Essential Oils from Four Ruta Species Growing in Algeria," Food Chemistry, Vol. 141, No. 1, 2013, pp. 253-258. doi:10.1016/j.foodchem.2013.03.007

[25] T. Narmadha, V. Sivakami and J. Gunaseela, "Antimicrobial Activity of Essential Oils against Wound Infective Bacteria," World Journal of Science and Technology, Vol. 2, No. 8, 2013, pp. 15-18.

[26] R. N. Peixoto, G. Guilhon, M. das Graças, B. Zoghbi, I. S. Araújo, A. P. T. Uetanabaro, L. S. Santos and D. do S. B. Brasil, "Volatiles, a Glutarimide Alkaloid and Antimicrobial Effects of Croton pullei (Euphorbiaceae)," Molecules, Vol. 18, No. 3, 2013, pp. 3195-3205. doi:10.3390/molecules 18033195

[27] A. Gbolade, C. Argyropoulou and H. Skaltsa, "Essential Oil Analysis of the Peel and Leaf Oils of Citrus medica L. (Rutaceae) from Nigeria," Nigerian Journal of Natural Products and Medicine, Vol. 15, No. 1, 2011, pp. 62-65.

[28] A. Karioti, H. Skaltsa and A. A. Gbolade, "Constituents of the Distilled Essential Oils of Citrus reticulata and $C$. paradisi from Nigeria," Journal of Essential Oil Research, Vol. 19, No. 6, 2007, pp. 520-522. doi:10.1080/10412905.2007.9699320

[29] M. Okeke, C. Iroegbu, E. Eze, A. Okoli and C. Esimone, "Evaluation of Extracts of the Root of Landolphia owerrience for Antibacterial Activity," Journal of Ethnopharmacology, Vol. 78, No. 2-3, 2001, pp. 119-127. doi:10.1016/S0378-8741(01)00307-5

[30] A. Farhat, A. Fabiano-Tixier, M. El Maataoui, J. Maingonnat, M. Romdhane and F. Chemat, "Microwave Steam Diffusion for Extraction of Essential Oil from Orange Peel: Kinetic Data, Extract's Global Yield and Mechanism," Food Chemistry, Vol. 125, No. 1, 2011, pp. 255261. doi:10.1016/i.foodchem.2010.07.110

[31] C. M. Lin, S. R. Sheu, S. C. Hsu and Y. H. Tsai, "Determination of Bactericidal Efficacy of Essential Oil Extracted from Orange Peel on the Food Contact Surfaces," Food Control, Vol. 21, No. 12, 2010, pp. 17101715. doi:10.1016/j.foodcont.2010.06.008

[32] M. Ahmad, Salim-ur-Rehman, Z. Iqbal, F. Anjul and J. Sultan, "Genetic Variability to Essential Oil Composition in Four Citrus Fruit Species," Pakistan Journal of Botany, Vol. 38, No. 2, 2006, pp. 319-324.

[33] S. A. Vekiari, E. E. Protopapadakis, P. Papadopoulou, D. Papanicolaou, C. Panou and M. Vamvakias, "Composition and Seasonal Variation of the Essential Oil from Leaves and Peel of a Cretan Lemon Variety," Journal of Agricultural and Food Chemistry, Vol. 50, No. 1, 2002, pp. 147-153. doi:10.1021/jf001369a

[34] R. Dabbah, V. Edwards and W. Moats, "Antimicrobial Action of Some Citrus Fruit Oils on Selected Food-Borne Bacteria," Applied Microbiology, Vol. 19, No. 1, 1970, pp. 27-31. 
[35] D. R. Caccioni, M. Guizzardi, D. M. Biondi, A. Renda and G. Ruberto, "Relationship between Volatile Components of Citrus Fruit Essential Oils and Antimicrobial Action on Penicillium digitatum and Penicillium italicum," International Journal of Food Microbiology, Vol. 43, No. 1-2, 1998, pp. 73-79. doi:10.1016/S0168-1605(98)00099-3

[36] M. Viuda-Martos, Y. Ruiz-Navajas, J. Fernández-López and J. Pérez-Álvarez, "Antifungal Activity of Lemon (Citrus lemon L.), Mandarin (Citrus reticulata L.), Grapefruit (Citrus paradisi L.) and Orange (Citrus sinensis L.) Essential Oils," Food Control, Vol. 19, No. 12, 2008, pp. 1130-1138. doi:10.1016/i.foodcont.2007.12.003

[37] I. Zukerman, "Effect of Oxidized D-Limonene on MicroOrganisms," Nature, Vol. 168, 1951, p. 517. doi:10.1038/168517a0

[38] M. U. Unal, F. Ucan, A. Sener and S. Dincer, "Research on Antifungal and Inhibitory Effects of DL-Limonene on Some Yeasts," Turkish Journal of Agriculture and Forestry, Vol. 36, 2012, pp. 576-582. doi:10.3906/tar-1104-41
[39] D. Stojković, J. Petrovic, M. Sokovic, J. Glamoclija, J. Kukić-Markovic and S. Petrovic, "In Situ Antioxidant and Antimicrobial Activities of Naturally Occurring Caffeic Acid, p-Coumaric Acid and Rutin, Using Food Systems," Journal of the Science of Food and Agriculture, 2013. doi:10.1002/jsfa.6156

[40] R. M. Boxtel, R. S. Lambrecht and M. T. Collins, "Effect of Polyoxyethylene Sorbate Compounds (Tweens) on Colonial Morphology, Growth, and Ultrastructure of $M y$ cobacterium paratuberculosis," Apmis, Vol. 98, No. 7-12, 1990, pp. 901-908. doi:10.1111/j.1699-0463.1990.tb05013.x

[41] J. Y. Li, L. W. Zhang, M. Du, X. Han, H. X. Yi, C. F. Guo, Y. C. Zhang, X. Luo, Y. H. Zhang and Y. J. Shan, "Effect of Tween Series on Growth and Cis-9, Trans-11 Conjugated Linoleic Acid Production of Lactobacillus acidophilus F0221 in the Presence of Bile Salts," International Journal of Molecular Sciences, Vol. 12, No. 12, 2011, pp. 9138-9154. doi:10.3390/ijms12129138 